\title{
Iranian EFL Teachers' Willingness to Implement Postmethod Pedagogy: Development and Validation of a Questionnaire
}

\author{
Jalil Fathi
}

University of Kurdistan, Iran, jfathi13@yahoo.com

Razieh Hamidizadeh

MA in TEFL, Islamic Azad University, Malayer Branch

The current study details the development and validation of a measuring instrument for the teachers' willingness to implement postmethod pedagogy principles in the Iranian context. Three postmethod components were identified after (1) undertaking a comprehensive review of the literature on the postmethod pedagogy and second language (L2) teacher education and (2) conducting interviews with domain experts and practicing language teachers. In Phase 1 of the study, an exploratory factor analysis (EFA) was conducted with a randomly selected and nationally representative sample $(\mathrm{N}=255)$ of Iranian EFL teachers, resulting in three internally consistent factors: (a) Teacher Sense of Social Justice, (b) Teacher Autonomy, and (c) Teacher Sense of Academic Enthusiasm. In Phase 2 of the study, a confirmatory factor analysis (CFA) was completed with a new sample $(\mathrm{N}=648)$ of practicing teachers. Strong model fit estimates in Phase 2 confirmed the factor structure of Phase 1 and resulted in a final 29-item scale called "Postmethod Scale" (PMS).

Keywords: postmethod, EFL teachers, validation, scale, teachers' willingness

\section{INTRODUCTION}

Since the last three decades, language teaching profession has witnessed a dramatic shift of attention and orientation in the sense that more of the reality of the lives of both students and teachers have been taken into account (Tudor, 2003). One of these conceptual shifts which have received much attention is the disappearance of method (Allwright, 1991) from academic discussions and the rise of the postmethod debate (Kumaravadivelu, 1994). The postmethod debate criticized the search for the better method (Allwright, 1991; Fat'hi \& Behzadpour, 2011). Kumaravadivelu, 1994; Prabhu, 1990), although its practical counterpart, that is, methodology, is still a legitimate notion and very much alive to many teachers (Bell, 2007).

Citation: Fathi, J., \& Hamidizadeh, R. (2019). Iranian EFL Teachers' Willingness to Implement Postmethod Pedagogy: Development and Validation of a Questionnaire. International Journal of Instruction, 12(1), 165-180. https://doi.org/10.29333/iji.2019.12111a 
The early undocumented roots of post-method can be traced to what the profession has called eclecticism. The postmethod condition questions the legitimacy of the concept of the method. In other words, post-method pedagogy, as proposed by Kumaravadivelu (1994) emerged as a response to a call for the most optimal way of teaching English that would free itself from the method-based stranglehold. The postmethod pedagogy tries to explore the instructional means for real life communication in the second language (L2) classroom and to get the learners not just to develop linguistic accuracy, but to expand their fluency. From this perspective, learners are assumed to be partners in a cooperative venture, and they are persuaded to move toward the fulfillment of their fullest potential (Brown, 2001; Kumaravadivelu, 2001). Although "postmethod pedagogy" (Kumaravadivelu, 2001) has extricated ELT professionals and practitioners from many of the constraints of the concept of method and invigorated the classroom practices by providing new options to the classroom teacher, the postmethod pedagogy has brought with it its own new constraints and has been criticized occasionally (Akbari, 2008; Bell, 2003; Block, 2001).

The significant though contentious role of postmethod pedagogy in ELT and also the importance of the thoughts and cognition of teachers in shaping their behavior and actions (Borg ,2003) provided the primary incentive for the current study.

Unlike the conventional methods, the new postmethod pedagogy is considered to be more flexible since it adopts macrostrategies to shape microstrategies. Despite some superficial appeal which came with this so-called flexibility and getting rid of the limitations of method, the postmethod pedagogy has been criticized from different angles (Akbari, 2008; Bell, 2003, 2007; Larsen-Freeman, 2005a,b; Liu, 1995). Akbari (2008) claims that the postmethod is qualitatively not much different from method because both of them ignore or misrepresent the realities of the classroom and impose their own version of hypothetical reality. Akbari (2008) further adds:

While method has ignored the realities of teaching and language teachers, postmethod has ignored the realities of teaching and language teachers. By making too many demands of teachers, the post-method pedagogy, in practice, turned a blind eye to the social, political and cultural realities of language teaching contexts and the limits within which teachers operate. (p. 642)

Since its inception, the postmethod pedagogy has evoked much controversy and debate among ELT community all over the world. Sometimes, even it has been the target of much criticism (Akbari, 2008; Bell, 2003; Brown, 2000). Despite the legitimacy of this healthy debate regarding postmethod pedagogy, the Iranian teacher education program still suffers from the agony of indecision and a state of uncertainty with regard to the postmethod pedagogy (Gholami \& Mirzaei, 2013; Khatib \& Fat'hi, 2014; Razmjoo, Ranjbar \& Hoomanfard, 2013). No systematic effort has been made to uncover the realities concerning both Iranian ELT teachers' and Iranian domain expert's mentality and beliefs about postmethod pedagogy. Since the domain experts in ELT have a professional experience and understanding of the Iranian context, their perspectives regarding the postmethod has definitely much to offer to those who are engaged in the profession of language pedagogy in Iran. 
Despite all the theoretical developments in applied linguistics during the past two decades, teacher education policies at various levels of assessment, training and certification of prospective teachers have been largely affected by popular perceptions and beliefs (Freeman, 2002). As a result, some of the educational policies adopted by the current programs of teacher education worldwide are not inspired by a solid and research-based understanding of the teaching process but by the established myth of how teachers go about teaching. However, recent decades have witnessed a growing interest in both researchers' community and practitioners' community to explore and make use of the mental images, thoughts and processes which L2 teachers employ while teaching (Ellis \& Freeman, 2006; Lantolf \& Thorne, 2006). Admittedly, there is a need to listen to teachers' voices in understanding classroom practice (Richards \& Farrell, 2005). As Clemente (2001) convincingly argues, a holistic approach to teaching a language should include the personal side of teaching; the way teachers feel about various parameters of their practice.

According to some researchers (Hargreaves, 1994; Freeman, 1990; Prabhu, 1992) teachers' performance in a class is shaped by "minds" and "attitudes". As Freeman (1990) maintains, attitudes are such important factors that can be considered as the cause of teachers' either success or failure.

Given the due significance of the teachers' attitude and also the way teachers see themselves in relation to their work, and also with the emergence of postmethod pedagogy which defines a new relationship between teachers and theorizers by fostering teachers' skills, knowledge, and sense of autonomy (Kumuravadevelu, 2006b), the Iranian EFL teachers' perceptions and attitudes concerning the postmethod pedagogy has remained an uncharted territory. Therefore, an area which seems to be in dire need of scholarly research in the realm of Iranian teacher education is the investigation of Iranian EFL teachers' willingness to implement postmethod pedagogy principles in the Iranian context. Given the contentious nature of the postmethod pedagogy and also the particular context of Iran, the conduction of a nation-wide survey to investigate Iranian EFL teachers' willingness to implement postmethod pedagogy principles might be considered as a worthwhile exploration. As a part of a larger project, the aim of this study was to develop and validate a scale for measuring EFL teachers' willingness to implement postmethod pedagogy principles.

\section{REVIEW OF LITERATURE}

This newer understanding in foreign language teaching methodology has been described as the postmethod condition because of its underlying beliefs and assumptions concerning foreign language teaching practices. As Kumaravadivelu (2006a) describes it:

The postmethod condition is a sustainable state of affairs that compels us to fundamentally restructure our view of language teaching and teacher education. It urges us to review the character and content of classroom teaching in all its pedagogical and ideological perspectives. It drives us to streamline our teacher 
education by refiguring the reified relationship between theory and practice.(p.170)

In contrast to the concept of method, post-method pedagogy does not have the commonly-referred-to limitations as it is not an alternative method but "an alternative to method" (Kumaravadivelu, 2003, p. 32). Post-method pedagogy puts the teacher at the center of language learning and teaching and values his/her beliefs, experiences and knowledge. The value given to teachers should be appreciated because it is the teachers who are more likely to know their learners and the classroom context better.

Teachers play a key role in second language education because of their experience in the past as students, past experience of teaching, knowledge of one or more methods gained throughout their training as teachers, knowledge of other teachers' actions and opinions and their experience as parents or caretakers (Prabhu, 1990). Therefore, post-method teachers are encouraged to develop and create their own methods as they gain experience based on their classroom context and knowledge of other methods and approaches. As a result, the constructed method reflects teachers' beliefs, values and experiences (Richards \& Rodgers, 2001). In this sense, post-method teachers are autonomous, analysts, strategic researchers and decision-makers. Such teachers are also reflective as they observe their teaching, evaluate the results, identify problems, find solutions, and try new techniques. Based on this, there is a movement from "scienceresearch conceptions" towards "art-craft conception of teaching" (Arikan, 2006, p. 4) as well as a shift from top-down process to bottom-up process as teachers "theorize what they practice or practice what they theorize" (Kumaravadivelu, 2003, p. 37). One should notice that post-method does not disregard the knowledge of existing methods and approaches because these methods make you aware of your beliefs and principles and provide inexperienced teachers with some valuable initial knowledge (Khatib, \& Fat'hi, 2012; Richards \& Rodgers, 2001).

This dramatic shift and change from the method era to postmethod era indicates a shift from a positivist-oriented perspective to a constructivist-oriented one and "a shift from transmission, product-oriented theories to constructivist, process-oriented theories of learning, teaching, and teacher learning" has been particularly conspicuous (Crandall, 2000 , pp. 34-35). Brown (2000) maintains that constructivism sprang into being as a dominant paradigm only in the last part of the twentieth century. Similarly, he points out that constructivists conceive of reality as socially-constructed and it is now an accepted practice to hold various constructions of knowledge. Thus, this new conception of knowledge puts the act of learning in an entirely different context. As Cunningham (2001) explains, "constructivism views learning as an active process where learners reflect upon their current and past knowledge and experiences to generate new ideas and concepts" (p. 2). As a consequence, "a shift to a constructivist perspective of teaching and teacher learning makes teachers a primary source of knowledge about teaching" (Crandall, 2000, p. 35), and this, in turn, has paved the road for democratic approaches of teaching to come to the fore. As Akbari (2005) puts it, new avenues are being probed and language teaching is no longer merely determined by theoreticians. He sums it up "the shift in paradigm is due to the change of scope observed in modern language 
teaching literature and a concern for disciplines and issues previously regarded as irrelevant by both practitioners and theoreticians" (p. 14).

Apparently such a dramatic shift is bound to have some ramifications. As Akbari (2005) and Pica (2000) explicate the post method condition is typical of such transitions and is one of the concepts that echo the above-mentioned changes in language teaching. The recurring discontent with the notion of method and the technician model of teacher education gave rise to postmethod (Kumaravadivelu, 2001). The top-down criticism levelled against the concept of method entails its being too prescriptive in the sense that teachers don't seem to have any voice in what to teach and how to teach it (Crandall, 2000; Kumaravadivelu, 1994; Pennycook, 1989; Richards \& Rodgers, 2001). In comparison with the traditional teacher education which "views teachers as passive recipients of transmitted knowledge rather than active participants in the construction of meaning ... and which does not take into account the thinking or decision-making of teachers" (Crandall, 2000, p. 35), the postmethod condition is a practice-driven construct which calls into question the traditional conceptualization of teachers as a channel of received knowledge (Kumaravadivelu, 1994, 2003); it raises serious questions regarding the traditional dichotomy between theorizers and practitioners with a view to empowering teachers whereby they can "theorize what they practice and practice what they theorize" (Kumaravadivelu, 2001; p. 545). In this era "it is teachers who have to act as mediators between theory and practice, between the domain of disciplinary research and pedagogy" (Widdowson, 1990, p. 22). As it is argued by Kumaravadivelu (2001), any pedagogy is a politically-charged process in which particularity is embedded in active awareness of local conditions. Within the pedagogy of particularity as one of the constituents of the postmethod debate, teachers are entrusted with "observing their teaching acts, evaluating their outcomes, identifying problems, finding solutions, and trying them out to see once again what works and what does not" (p. 539). In fact, teacher autonomy is a key component of postmethod in a way that "it can be seen as defining the heart of postmethod pedagogy" (Kumaravadivelu, 2001, p. 548). To summarize, and borrowing on Akbari (2005):

The postmethod condition is a more democratic approach to language teaching profession since it assigns a voice to practitioners and respects the type of knowledge they possess. In addition, it is a liberating move which gives teachers more autonomy and confidence in the decisions they make in their classes. (p. 5)

In a nutshell, within this framework, teachers play a pivotal role in language classes and the heightened interest in taking teachers into account as the focal point of education is manifest in the strikingly increasing number of journal articles dealing with language teacher education (Clarke, 1994). Since postmethod problematizes the traditional concept of method, there is a need for alternatives that can help teachers materialize the objectives set by postmethod.

The postmethod pedagogy is characterized by leaving methods-only arguments to find effective strategies to teach in the most appropriate and effective way while considering the practitioner's views and roles in preparing and teaching language materials. Hence, 
according to the general perception of postmethod era, instead of looking for which language teaching method is the best to follow, the language teacher must find the most effective strategies and techniques to enrich her or his teaching repertoire. This understanding of the individual journey of the language teacher has grown in contrast to the mainstream and widespread model of language teacher education programs which were characterized by imposing methodological concerns rather than inviting the individual language teacher to find her or his way to best teaching practices.

The postmethod pedagogy as proposed by Kumaravadivelu (2006a) is concerned with three types of parameters or principles: The Parameter of Particularity, The Parameter of Practicality and The Parameter of Possibility.

As far as the parameter of particularity is concerned, post-method pedagogy emphasizes the key aspect of local context or what Kumaravadivelu calls "situational understanding" (p.171). From the perspective of this parameter, L2 policy makers and administrators will pay attention to local contingencies and, most probably, make do with whatever is amenable to teaching effectiveness.

With regard to the parameter of practicality, post-method pedagogy suggests that, rather than being overly concerned about what outside experts have to say regarding teaching efficacy, local teachers should themselves begin to seek avenues that will help them teach and their students learn in a most successful way. They are not supposed to follow in the footsteps of any teaching "gurus". In the words of Kumaravadivelu:

[t]he parameter of practicality, then, focuses on teachers' reflection and action, which are also based on their insights and intuition. Through prior and ongoing experience with learning and teaching, teachers gather an unexplained and sometimes explainable awareness of what constitutes good teaching. (p.173)

Parameter of possibility aims at providing a more comprehensive context for language teaching in terms of its social engagement and political accountability. From this perspective, post-method pedagogy considers L2 teaching and learning not as grasping new linguistic and cultural knowledge but as a site of struggling between the old and new identities for teachers and learners alike. That is to say, L2 teaching is seen more as a tool to help learners come to grips with their own identity and as a vehicle to explore other peoples and cultures. This parameter of possibility enables L2 learners to adopt a critical mindset towards their L2 learning experiences. In other words, an L2 they are attempting to acquire will be not just a new linguistic experience but, more importantly, a new lens through which to appreciate the world out there and the world inside, hence the global and local becoming part and parcel of the whole L2 experience.

As Kumaravadivelu (2006b) maintains, there seems to be a shift toward a post-method era that defines a new relationship between teachers and theorizers, which is pushing teachers towards the world of skills, knowledge, and autonomy. Through empowerment and pedagogical insights gained, teachers are able to theorize based on their practice and practice theories. As a result, some renewed attempts are being made to explore new educational patterns in Teaching English as a Foreign Language (TEFL). 


\section{METHOD}

\section{Participants and Sampling}

The participants recruited for the purpose of the present study were practicing English language teachers in Iran with different ages, genders, and educational backgrounds and teaching experience. The respondents to the questionnaire were 944 teachers in total who included 41 for the initial piloting, 255 for the Exploratory Factor Analysis (EFA), and finally 648 for the Confirmatory Factor Analysis (CFA). In fact, the validation process was carried out by distributing the developed instrument to a total of 1400 practicing English language teachers at different institutes, schools, and centres of higher education in different Iranian cities such as Tehran, Karaj, Kermanshah, Sanandaj, Isfahan, Mashhad, Shiraz and Tabriz. As for the sampling procedure, a combination of stratified random sampling and cluster sampling (Ary, et al.,2010) was utilized. Different provinces were selected as the strata; and the schools, language centers, and universities were selected as the cluster. Both face to face methods and emails were used for instrument distribution. Out of the 1400 distributed questionnaires, 995 instruments were completed by the respondents and returned to the researcher (a return rate of $71 \%$ ). Upon close inspection of the completed questionnaires, 51 of the completed instruments were discarded since they were either incomplete or carelessly completed (for example those questionnaires in which one response was systematically selected). This left the researcher with the total number of 944 completed questionnaires with the details as mentioned above.

In the meantime, a number of 5 domain experts and 5 practicing teachers also commented on the wording of the items, content, and construct of the questionnaire developed. The expert members of this panel were also consulted for the components of the model hypothesized and tested.

\section{Procedure}

With regard to the procedure, the steps employed by Nikitina et al. (2016) were taken into account. As Dornyei (2010) puts it "developing a questionnaire is a stepwise process, and the quality of the final instrument depends on the cumulative quality of each sub-process"(p.111). To develop a reliable and valid questionnaire, the three major steps of model development, item formulation and initial piloting, and model validation were drawn upon by the researcher.

\section{Model Development}

In order to develop the questionnaire for measuring the degree of willingness of Iranian EFL teachers towards postmethod pedagogy, the first step was to take a theoretical model as the point of departure. In so doing, first of all, the related literature concerning postmethod pedagogy was comprehensively scrutinized by the researcher. Following the literature review phase and in order to complement the findings, the tentative model of postmethod pedagogy developed from the literature was triangulated using data from semi-structured interviews with the domain experts. Then, three underlying components for postmethod pedagogy were identified after the scrutiny and analysis of both the 
related literature and interview transcripts. The three extracted components were three principles of particularity, practicality and possibility as proposed by Kumaravadivelu (1994).

\section{Item Formulation and Initial Piloting}

The conceptual framework of postmethod pedagogy consisting of the three principles of particularity, practicality and possibility as proposed by Kumaravadivelu (1994) was used to formulate items for the postmethod pedagogy instrument. In order to guarantee the representativeness of the content for a construct under investigation, the first job was to review the literature and then generate the items based on already developed questionnaires. Since no previously published questionnaire existed for postmethod pedagogy, the researcher had to resort to self-initiative item generation. The first task was to activate the imagination and have an eye on the theoretical foundation of the model and come up with an 'item pool' (Dorney, 2010).

After generating the items, the items were checked by the panel of domain experts for their face validity, format, representativeness ,accuracy, wording and intelligibility. Sixoption rating scale, ranging from strongly disagree to strongly agree, was opted for the items of the scale. According to Dörnyei (2010), some respondents are generally conservative in their responses and are very likely to choose 'no idea: undecided' in some apparently sensitive items. Therefore, six-option rating scale in which 'neutral' option was changed into two options of 'slightly disagree' and 'slightly agree' was employed in the present study.

Up to this stage, the draft version of the questionnaire consisted of 42 items. In this stage, the near-final questionnaire was administered to 41 practicing teachers who were teaching at different institutes in Tehran. This was an "undeclared" pre-test whereby the respondents are not told that this is a questionnaire under construction (Converse \& Presser, 1986). The feedbacks were very conducive in modifying some of the items in terms of the wording and discarding two problematic items. The two items were the questions whose wording was ambiguous or were too difficult for the respondents to reply to. Hence, the remaining questionnaire included 40 items. Results of the pilot study were fed into SPSS to check the reliability of the instrument using Cronbach Alpha reliability.

The results for the Cronbach's Alpha showed that the internal consistency of the whole questionnaire was 0.80 and for the three subscales of practicality, particularity and possibility (i.e. the three components of postmethod pedagogy) in the questionnaire the reliability was estimated to be $0.80,0.64$, and 0.72 respectively. The values of internal consistency exceeding 0.60 are considered to be acceptable (Dornyei \& Taguchi, 2009, p. 95).

\section{Model Validation}

In the present study, the validation scheme proposed by Mulaik and Millsap (2000), consisting of Exploratory Factor Analysis (EFA), Confirmatory Factor Analysis (CFA) and Model Evaluation, was used. For the ease of discussion, the validation process was divided into two macro-phases in this study: Exploratory Data Analysis (EDA) and Confirmatory Data Analysis (CDA). 


\section{FINDINGS}

\section{Phase 1: Exploratory Factor Analysis}

EFA of the data from the first group of teachers filling out the draft version of the PMS was carried out using MPlus 7.0 (Muthén \& Muthén, 2010). The Kaiser-Meyer-Olkin (KMO) measure of sampling adequacy was 0.83 and Bartlett's test of sphericity was significant $(p<.001)$, indicating that the inter-correlations among the items in the questionnaire was strong enough to conduct factor analyses (Pallant, 2011). Both indices confirmed the factorability of the data.

Several principal axis factor (PAF) analyses followed by Promax rotation showed that three factors could be extracted which could account explain $46 \%$ of the variance. The extracted factors could individually account for $15.38 \%, 16.65 \%$, and $13.97 \%$ of the total variance. The decision concerning the number of factors to be retained was guided by interpretability of the results, factors explaining over 1 eigenvalue, parallel analysis and minimum average partial correlation. In addition, theoretical background of the questionnaire was also taken into account adhering to recommendations made by Henson and Roberts (2006) and Zwick and Velicer (1986) to make a more accurate decision regarding the number of factors.

After checking the factor loadings, it was revealed that the 29 items out of 40 items were acceptably loaded on the three factors. More specifically, the 40-item scale was reduced to a 29 -item one by removing the items with loadings lower than .40 and those that clearly loaded on more than one factor.

Table 1

Factor Correlations in Phase 1 (EFA) and Phase 2 (CFA)

\begin{tabular}{|c|c|c|c|}
\hline & Justice & Autonomy & Academic optimism \\
\hline \multicolumn{4}{|l|}{ Phase 1} \\
\hline Justice & 1.00 & & \\
\hline Autonomy & $0.27 *$ & 1.00 & \\
\hline Academic optimism & 0.08 & $0.24 *$ & 1.00 \\
\hline \multicolumn{4}{|l|}{ Phase 2} \\
\hline Justice & 1.00 & & \\
\hline Autonomy & $0.21 *$ & 1.00 & \\
\hline Academic optimism & 0.12 & $0.31 *$ & 1.00 \\
\hline
\end{tabular}

The factor loadings of the 29 items of the questionnaire indicated the groupings of the particular items. To interpret the groupings of items, the items being clustered together under the same factor were studied carefully to find out if there was any commonality among them and whether items grouped together could create new underlying construct for postmethod pedagogy. Items 29, 33, 34, 35, 36, 37, 38, 39, 26, 22 were loaded on factor 1, Items 2, 4, 5, 7, 8, 13, 20, 24, 25, 27 were loaded on factor 2, and items 6, 10, $11,12,15,16,17,19,23$ were loaded on factor 3 . Compared to the conceptual framework, the results of factor analysis indicated a number of changes to the grouping of items and the organization of categories. The first factor, which accounts for 
$15.38 \%$, of the total variance, consists of 10 items belonging to two different categories in the conceptual model. Items 22 and 26 were classified under the Particularity in the conceptual framework, whereas the remaining items of $29,33,34$, $35,36,37,38$, and 39 were subsumed under the Possibility.

A closer scrutiny of the content of this factor showed that all the items are related to teacher's knowledge and awareness of the socio-political issues, therefore, this factor was labelled as Teacher Sense of Social Justice.

The second factor, explaining $16.65 \%$, of the total variance, consists of 10 items (Items $2,4,5,7,8,13,20,24,25$, and 27) among which items $2,4,5,7,8$, and 13 were related to Practicality category in the conceptual model. Items 20, 24, 25, and 27 belonged to the Particularity category of the conceptual model. An inspection of the commonalities of these items revealed that they all refer to the freedom of teachers in their decision making in their classrooms hence receiving the title Teacher Autonomy.

Table 2

Postmethod Scale Exploratory Factor Analysis $(\mathrm{N}=255)$

\begin{tabular}{|c|c|c|c|c|}
\hline \multirow{2}{*}{ Construct } & \multirow{2}{*}{ Indicators } & \multicolumn{3}{|c|}{ Loadings } \\
\hline & & & 2 & 3 \\
\hline \multirow{9}{*}{$\begin{array}{l}\text { Justice (1) } \\
(\alpha=0.82)\end{array}$} & \#22 I am not sensitive to the local educational, institutional and social contexts in which I am teaching. & $0.66^{*}$ & 0.08 & 0.19 \\
\hline & $\begin{array}{l}\text { \#26 I believe in a location-specific pedagogy that is based on a true understanding of local linguistic, sociocultural, and } \\
\text { political particularities of the language learner. }\end{array}$ & d $0.72 *$ & 0.06 & 0.08 \\
\hline & \#29 I try to use authentic teaching materials which are based on the local culture. & $0.62 *$ & 0.08 & 0.2 \\
\hline & \#33 I think dialogues and topics based on learners' real experiences can help them develop their critical thinking. & $0.78^{*}$ & -0.12 & 0.10 \\
\hline & $\begin{array}{l}\text { \#34 I think the teacher is not supposed to help students bring about change in their lives in overcoming poverty, social and } \\
\text { gender discrimination. }\end{array}$ & d $0.81 *$ & 0.06 & -0.10 \\
\hline & \#35 I think about the ways gender, social class, and race influence my students' achievements. & $0.85^{*}$ & 0.06 & 0.09 \\
\hline & \#36 I try to include issues of social injustice, poverty and discrimination as part of my teaching practice. & $0.88^{*}$ & 0.03 & 0.09 \\
\hline & \#37 I am not willing to know about the lives of my students and use their life experiences in my teaching practice. & $0.60^{*}$ & 0.06 & 0.03 \\
\hline & \#38 I try to relate what is happening in the classroom to what is taking place in the world outside the classroom. & $0.60 *$ & -0.21 & 0.01 \\
\hline \multirow{11}{*}{$\begin{array}{l}\text { Autonomy } \\
(2)(\alpha= \\
0.74)\end{array}$} & \#39 I don't try to create a sense of critical thinking towards social and political issues in my classes. & $0.69 *$ & 0.05 & 0.07 \\
\hline & \#2 I feel I lack the knowledge and skill to construct my own theory of practice in the classroom. & 0.12 & $0.85^{*}$ & 0.16 \\
\hline & \#4 I have my own personal conceptualization of how my teaching leads to desired learning. & 0.16 & $0.61 *$ & 0.17 \\
\hline & \#5 The materials which I use in my classes are chosen for the most part by me. & -0.10 & $0.83^{*}$ & 0.06 \\
\hline & \#7 In my teaching, I use my own methodology, guidelines, strategies and procedures. & -0.06 & $0.84 *$ & 0.14 \\
\hline & \#8 I have the freedom to be creative in my teaching approach. & 0.12 & $0.72 *$ & 0.08 \\
\hline & $\begin{array}{l}\text { \#13 I have the authority in language teaching and use my personal judgment in making pedagogical decisions in the } \\
\text { classroom. }\end{array}$ & e -0.04 & $0.85^{*}$ & -0.14 \\
\hline & \#20 I pay attention to the specific needs of my students in their specific context. & 0.05 & $0.79^{*}$ & 0.17 \\
\hline & \#24 I employ different methods and different materials in my different classes. & 0.03 & $0.87^{*}$ & 0.04 \\
\hline & $\begin{array}{l}\text { \#25 I believe the knowledge about how to teach cannot be found in the books but the teacher himself/herself should, based } \\
\text { on the context, generate such knowledge. }\end{array}$ & -0.11 & $0.83^{*}$ & 0.03 \\
\hline & \#27 I reflect to explore what works and what does not work with a particular group of learners in a particular context. & 0.08 & $0.68^{*}$ & 0.02 \\
\hline \multirow{9}{*}{$\begin{array}{l}\text { Academic } \\
\text { enthusiasm } \\
(3) \\
(\alpha=0.88)\end{array}$} & \#6 I rarely participate in workshops/conferences related to language teaching/learning issues. & 0.08 & 0.17 & $0.89^{*}$ \\
\hline & \#10 I share my classroom experiences with my colleagues and ask for their advice /feedback. & -0.10 & 0.04 & $0.82 *$ \\
\hline & \#11 I read books/articles related to effective language teaching to improve my classroom performance. & 0.03 & -0.05 & $0.67 *$ \\
\hline & \#12 As a teacher, I am always thinking about how to develop my language teaching knowledge. & 0.14 & -0.00 & $0.68^{*}$ \\
\hline & \#15 I look for ways to create opportunities for teachers like myself to have their voices through journals and conferences. & 0.23 & 0.13 & $0.65^{*}$ \\
\hline & \#16 I write down significant aspects of my teaching in a journal as a source of teaching ideas and research. & 0.08 & 0.06 & $0.72 *$ \\
\hline & \#17 I try to relate the abstract theories to my own practice in the classroom. & -0.03 & -0.02 & $0.86^{*}$ \\
\hline & $\begin{array}{l}\# 19 \text { I try to test, interpret, and judge the usefulness of professional theories proposed by experts in the field of langu } \\
\text { teaching. }\end{array}$ & & -0.05 & $0.85^{*}$ \\
\hline & \#23 I rarely carry out classroom research to find local solutions to my students' local problems. & -0.11 & 0.10 & $0.78^{*}$ \\
\hline
\end{tabular}

Similarly, the nine items that loaded on the third factor (i.e. Particularity) account for $13.97 \%$ of the total variance among which items $6,10,11,12,15,16,17$, and 19 were classified as Practicality category in the conceptual model while items 23 was subsumed under the Particularity category of the conceptual model. Again, after examining the commonalities between these items, it was revealed that these items can be an indicator of the teachers' interest in attending conferences, workshops and reading articles, 
journals and other kinds of academic engagement. This factor was, thus, labelled as Teacher Sense of Academic Enthusiasm. Table 3 depicts the grouping and loading of all the items onto the three factors in the EFA.

Concerning the reliability of the scale, Internal consistencies for the whole questionnaire and for the individual extracted factors were calculated through Cronbach alphas. The Cronbach alpha for the whole PMS was 0.90, indicating a high internal consistency among the items of the questionnaire. With regard to the individual extracted factors, the Cronbach alphas ranged from 0.74

(Factor 2; Teacher Autonomy) to 0.88 (Factor 3; Teacher Sense of Academic Enthusiasm). Moreover, the correlations between the factors ranged from 0.08 to 0.27 as shown in Table 1.

All in all, Study 1 suggests that the PMS consists of three factors. Each subscale demonstrated strong internal consistency. The findings of this study offer preliminary support for the feasibility of measuring willingness towards postmethod pedagogy with these items.

Table 3

Measurement Model: Confirmatory Factor Loadings $(\mathrm{N}=648)$

\begin{tabular}{|c|c|c|c|c|}
\hline Construct & Indicators & $\begin{array}{l}\text { Standardized } \\
\text { estimate }\end{array}$ & $S E$ & $R^{2}$ \\
\hline \multirow{9}{*}{$\begin{array}{l}\text { Justice (1) } \\
(\alpha=0.89)\end{array}$} & \multirow{3}{*}{$\begin{array}{l}\text { \#22 I am not sensitive to the local educational, institutional and social contexts in which I am teaching. } \\
\text { \#26 I believe in a location-specific pedagogy that is based on a true understanding of local linguistic, } \\
\text { sociocultural, and political particularities of the language learner. } \\
\text { \#29 I try to use authentic teaching materials which are based on the local culture. }\end{array}$} & $0.60^{*}$ & 0.06 & 0.36 \\
\hline & & $0.74 *$ & 0.05 & 0.54 \\
\hline & & $0.76^{*}$ & 0.05 & 0.57 \\
\hline & $\begin{array}{l}\# 33 \text { I think dialogues and topics based on learners' real experiences can help them develop their critical } \\
\text { thinking. }\end{array}$ & $0.63^{*}$ & 0.05 & 0.39 \\
\hline & $\begin{array}{l}\text { \#34 I think the teacher is not supposed to help students bring about change in their lives in overcoming } \\
\text { poverty, social and gender discrimination. }\end{array}$ & $0.83^{*}$ & 0.03 & 0.63 \\
\hline & \#35 I think about the ways gender, social class, and race influence my students' achievements. & $0.85^{*}$ & 0.06 & 0.72 \\
\hline & \#36 I try to include issues of social injustice, poverty and discrimination as part of my teaching practice. & $0.77 *$ & 0.03 & 0.59 \\
\hline & $\begin{array}{l}\text { \#37 I am not willing to know about the lives of my students and use their life experiences in my teaching } \\
\text { practice. }\end{array}$ & $0.63^{*}$ & 0.05 & 0.39 \\
\hline & $\begin{array}{l}\text { \#38 I try to relate what is happening in the classroom to what is taking place in the world outside the } \\
\text { classroom. }\end{array}$ & $0.88^{*}$ & 0.03 & 0.77 \\
\hline \multirow{11}{*}{$\begin{array}{l}\text { Autonomy } \\
(2)(\alpha= \\
0.76)\end{array}$} & \#39 I don't try to create a sense of critical thinking towards social and political issues in my classes. & $0.66 *$ & 0.05 & 0.43 \\
\hline & \#2 I feel I lack the knowledge and skill to construct my own theory of practice in the classroom. & $0.62 *$ & 0.05 & 0.38 \\
\hline & \#4 I have my own personal conceptualization of how my teaching leads to desired learning. & $0.56^{*}$ & 0.05 & 0.31 \\
\hline & \#5 The materials which I use in my classes are chosen for the most part by me. & $0.88^{*}$ & 0.05 & 0.77 \\
\hline & \#7 In my teaching, I use my own methodology, guidelines, strategies and procedures. & $0.93 *$ & 0.04 & 0.86 \\
\hline & $\# 8$ I have the freedom to be creative in my teaching approach. & $0.76^{*}$ & 0.05 & 0.57 \\
\hline & $\begin{array}{l}\text { \#13 I have the authority in language teaching and use my personal judgment in making pedagogical decisions } \\
\text { in the classroom. }\end{array}$ & $0.82^{*}$ & 0.04 & 0.67 \\
\hline & \#20 I pay attention to the specific needs of my students in their specific context. & $0.82 *$ & 0.05 & 0.67 \\
\hline & \#24 I employ different methods and different materials in my different classes. & $0.60^{*}$ & 0.06 & 0.36 \\
\hline & $\begin{array}{l}\text { \#25 I believe the knowledge about how to teach cannot be found in the books but the teacher himself/herself } \\
\text { should, based on the context, generate such knowledge. }\end{array}$ & $0.68^{*}$ & 0.06 & 0.46 \\
\hline & $\begin{array}{l}\text { \#27 I reflect to explore what works and what does not work with a particular group of learners in a particular } \\
\text { context. }\end{array}$ & $0.89^{*}$ & 0.03 & 0.79 \\
\hline \multirow{9}{*}{$\begin{array}{l}\text { Academic } \\
\text { enthusiasm } \\
\text { (3) }(\alpha= \\
0.86)\end{array}$} & \#6 I rarely participate in workshops/conferences related to language teaching/learning issues. & $0.93^{*}$ & 0.04 & 0.86 \\
\hline & \#10 I share my classroom experiences with my colleagues and ask for their advice /feedback. & $0.80^{*}$ & 0.05 & 0.64 \\
\hline & \#11 I read books/articles related to effective language teaching to improve my classroom performance. & $0.67 *$ & 0.05 & 0.44 \\
\hline & \multirow{6}{*}{$\begin{array}{l}\text { \#12 As a teacher, I am always thinking about how to develop my language teaching knowledge. } \\
\text { \#15 I look for ways to create opportunities for teachers like myself to have their voices through journals and } \\
\text { conferences. } \\
\text { \#16 I write down significant aspects of my teaching in a journal as a source of teaching ideas and research. } \\
\text { \#17 I try to relate the abstract theories to my own practice in the classroom. } \\
\text { \#19 I try to test, interpret, and judge the usefulness of professional theories proposed by experts in the field of } \\
\text { language teaching. } \\
\text { \#23 I rarely carry out classroom research to find local solutions to my students' local problems. }\end{array}$} & $0.81 *$ & 0.05 & 0.65 \\
\hline & & $0.84^{*}$ & 0.03 & 0.70 \\
\hline & & $0.73 *$ & 0.05 & 0.53 \\
\hline & & $0.60^{*}$ & 0.06 & 0.36 \\
\hline & & $0.80^{*}$ & 0.05 & 0.64 \\
\hline & & $0.79 *$ & 0.04 & 0.62 \\
\hline
\end{tabular}

Note. Item numbers correspond to the original 46 -item scale. ${ }^{*} p<.05$. 


\section{Phase 2: Confirmatory Factor Analysis}

According to the findings of the EFA phase, substantiated by the theoretical knowledge of postmethod and experts' opinion, a three factor model of postmethod pedagogy was extracted from the exploratory datasets and these three factor were labeled based on the shared characteristics and commonalities. This hypothetical model, then, had to be validated so that it could be used as a valid measurement instrument for measuring willingness and conformity of English language teachers towards postmethod pedagogy. The three-factor model identified through EFA in Study 1 was cross-validated by a CFA in Study 2, with a separate sample of participants randomly selected through stratified sampling (Worthington \& Whittaker, 2006). CFA of the data from the second group of learners was conducted using MPlus 7.0 (Muthén \& Muthén, 2010). The CFA sets up a measurement model for the PMS and is a more accurate test of underlying factor structure, in that items are restricted to only load on one factor; items' which load onto all other factors are fixed to zero in CFA (Muthén \& Muthén, 2010). Since an oblique rotational method (promax) was employed in the EFA, correlations between the three factors were estimated in the CFA.

The initial CFA showed an adequate fit to the data $(\mathrm{RMSEA}=.068, \mathrm{CFI}=.96, \mathrm{TLI}=$ .96 , WRMR $=1.04)$. RMSEA was above the suggested .06 cutoff for good fit, CFI and TLI were above the .95 cutoffs as proposed in the literature, and WRMR was a bit beyond the 1.00 cutoff for good fit (Hu \& Bentler, 1999; Kline, 2010). Nevertheless, modification indices of the model revealed that error covariances between some pairs of items should be estimated. Among these pairs, error covariances for three pairs of items (i.e., \#15 and \#6, \#20 and \#27, \#34 and \#36; see Table 3) were estimated. These three pairs may share common sources of error variance because of their semantic or wording similarities. Both substantive concerns and model modification indices guided these modifications.

Model fit indices revealed that hypothesized relationships between observed variables and their relevant latent construct were a very good fit to the data in the re-specified CFA $($ RMSEA $=.04, \mathrm{CFI}=.97, \mathrm{TLI}=.98, \mathrm{WRMR}=0.88)$.

Table 3 presents Cronbach alpha estimates, standardized factor loadings, standard errors, and $R^{2}$ values for the final CFA model. The standardized factor loadings were all statistically significant $(p<.05)$. All of the variables loaded onto the same factor in the CFA as they had in the EFA, indicating psychometric support for the PMS and its factor structure - particularly since the factor structure identified through EFA was replicated with a separate sample through CFA (Kline, 2010; Worthington \& Whittaker, 2006). Moreover, the pattern of factor correlations in the CFA was similar to the pattern of factor correlations in the EFA (see Table 1).

\section{CONCLUSION}

The purpose of the present study was to develop and validate a measuring instrument for the teachers' willingness to implement postmethod pedagogy principles in the Iranian context. The three principles of particularity, practicality and possibility as proposed by Kumaravadivelu (1994) served as the conceptual model for developing the postmethod 
pedagogy instrument. The study was conducted in two phases: Phase 1 used an EFA to test the factor structure of the PMS and obtained three internally consistent factors: (a) Teacher Sense of Social Justice, (b) Teacher Autonomy, and (c) Teacher Sense of Academic Enthusiasm. Phase 2 employed a CFA with a new sample, rigorously confirming the factor structure of Phase 1 and providing key construct validity evidence for the use of these items to measure these factors (Kline, 2010). The results of EFA and CFA analyses revealed that the developed and validated 29-item PMS has good psychometric properties (i.e. reliability and validity).

From a research point of view, a reliable and valid PMS can be employed by the researchers investigating the current state of postmethod pedagogy especially in the Iranian context. Using quantitative surveys, prospective researchers can make use of the validated scale in the present study in order to uncover the teachers' willingness to implement postmethod pedagogy principle. However, care should be taken that the process of validating a measuring instrument (e.g. a questionnaire) does not end once the instrument has been developed and initially validated.

As a result, further validation studies in several directions are called for. Future studies could further validate the PMS by examining the scale's convergence and divergence with related measures. The PMS should also be employed alongside qualitative research, probably as part of mixed-methods inquiry, as this would provide scholars with a way to explore the subjective experiences and meanings that EFL practicing teachers attach to postmethod pedagogy. In so doing, additional insight would be gained about how, why, when, and under what conditions postmethod pedagogy principles may — or may not — inform the teaching activities of EFL teachers.

As far as generalizability is concerned, care should be taken that wider application of the tested model and the developed PMS is constrained before further research. It should be acknowledged that Iranian context cannot represent all EFL contexts. Therefore, to increase the generalisability of the tested model and wider application of the developed and validated PMS, the cross-validation of the PMS with EFL learners within as wider number of EFL contexts is called for.

\section{REFERENCES}

Akbari, R. (2005). Recent Developments in Foreign Language Teaching. ROSHD FLT, $20,76,25-32$.

Akbari, R. (2007). Reflections on Reflective Teaching: A Critical Appraisal of Reflective Practices in L2 Teacher Education. System, 35(2), 192-207.

Akbari, R. (2008). Postmethod Discourse and Practice. TESOL Quarterly, 42(4), 641652.

Akbari, R., Behzadpoor, F., \& Dadvand, B. (2010). Development of English Language Teaching Reflection Inventory. System, 38, 211-227.

Allwright, R. L. (1991). The death of the method (Working Papers No. 10). Lancaster, England: The University of Lancaster, The Exploratory Practice Center. 
Allwright, D. (2003). Exploratory Practice: Rethinking Practitioner Research in Language Teaching. Language Teaching Research, 7(2), 113-141.

Arikan, A. (2006). Postmethod Condition and Its Implications for English Language Teacher Education. Journal of Language and Linguistics Studies, 2(1), 1-11.

Ary, D., Jacobs, L. C., Sorensen, C., \& Razavieh, A. (2010). Introduction to research in education (8 ed.). London: Wordsworth, Cengage Learning.

Bell, D. (2003). Method and Postmethod: Are They Really Incompatible? TESOL Quarterly, 37, 325-336.

Bell, D. (2007). Do Teachers Think that Methods are Dead? ELT Journal, 61, 135-143.

Block, D. (2001). An exploration of the art and science debate in language education. In M. Bax \& J.-W. Zwart (Eds.), Reflections on language and language learning: In honour of Arthur van Essen (pp. 63-74). Amsterdam: John Benjamins.

Borg, S. (2003). Teacher Cognition in Language Teaching: A Review of Research on What Language Teachers Think, Know, Believe, and Do. Language Teaching, 36(2), 81-109.

Brown, H. D. (2001). Teaching by principles: An interactive approach to language pedagogy. ( $2^{\text {nd }}$ ed.). NY: Addison Wesley Longman, Inc.

Brown, H. D. (2002). English language teaching in the "post-method" era: Towards better diagnosis, treatment, and assessment. In J. C. Richards \& W. A. Renandya (Eds.), Methodology in language teaching (9-18). Cambridge, England: Cambridge University Press.

Clarke, M. A. (1994). The Dysfunctions of the Theory/Practice Discourse. TESOL Quarterly, 28, 1, 10-27.

Clemente, M. A. (2001). Teachers Attitudes within a Self-directed Language Learning Scheme. System, 29, 45-67.

Crandall, J. A. (2000). Language Teacher Education. Annual Review of Applied Linguistics, 20, 34-55.

Cunningham, F. M. (2001). Reflecting Teaching Practice in Adult ESL Settings. ERIC Digest, 1-7.

Dornyei, Z. (2003). Questionnaires in Second Language Research: Construction, Administration, and Processing. New Jersey: Lawrence Erlbaum Associates, Inc., Publishers.

Dörnyei, Z. (2007). Research methods in applied linguistics. Oxford: Oxford University Press.

Dörnyei, Z. (2010). Questionnaires in second language research: Construction, administration, and processing ( $2^{\text {nd }}$ ed.). London: Routledge. 
Dornyei, Z., \& Taguchi, T. (2009). Questionnaires in second language research: Construction, administration, and processing. New York, NY: Routledge.

Ellis, N. C., \& Larsen-Freeman, D. (guest editors). (2006). Language Emergence. Applied Linguistics, 27, 554-740.

Fat'hi, J., \& Behzadpour, F. (2011). Beyond Method: The Rise of Reflective Teaching. International Journal of English Linguistics, 1(2), 241-251.

Freeman, D. (1990). Interviewing in practice teaching. In J. Richards, \& D. Nunan (Eds.). Second language teacher education. Cambridge: Cambridge University Press.

Freeman, D. (2002). The Hidden Side of the Work: Teacher Knowledge and Learning to Teach. Language Teaching, 35, 1-13.

Gholami, J., \& Mirzaei, A. (2013). Post-method EFL Teaching in Iran: Barriers, Attitudes and Symbols. Research Journal of English Language and Literature (RJELAL), 1(2), 50-64.

Hargreaves, A. (1994). Changing teachers, changing times. Cassell: London.

Henson, R.K., Roberts, J.K. (2006). Use of Exploratory Factor Analysis in Published Research : Common Errors and Some Comment on Improved Practice. Educational and Psychological Measurement, 66(3), 393-416.

Khatib, M., \& Fat'hi, J. (2012). Postmethod Pedagogy and ELT Teachers. Journal of Academic and Applied Studies, 2 (2), 22-29.

Khatib, M. \& Fat'hi, J. (2014). The Investigation of the Perspectives of Iranian EFL Domain Experts on Postmethod Pedagogy: A Delphi Technique. Journal of Teaching Language Skills (JLTS), 6 (3).

Kline, R. (2010). Principles and practice of structural equation modeling (3rd ed.). New York, NY: Guilford Press.

Kumaravadivelu, B. (1992). Macrostrategies for the Second/Foreign Language Teacher. Modern Language Journal, 76, 41-49.

Kumaravadivelu, B. (1993). Maximizing Learning Potential in the Communicative Classroom. ELT Journal, 47, 12-21.

Kumaravadivelu, B. (1994). The Postmethod Condition: (E)merging Strategies for Second/Foreign Language Teaching. TESOL Quarterly, 28(1), 27-48.

Kumaravadivelu, B. (2001). Toward a Postmethod Pedagogy. TESOL Quarterly, 35(4), 537-560.

Kumaravadivelu, B. (2005). In Defence of Postmethod. ILI Language Teaching Journal, 1(1), 15-19.

Kumaravadivelu, B. (2006a). Understanding language teaching: from method to postmethod. Mahwah, N. J.: Lawrence Erlbaum. 
Kumaravadivelu, B. (2006b). TESOL Methods: Changing Tracks, Challenging Trends. TESOL Quarterly, 40(1), 59-81.

Lantolf, J. P. \& Thorne, S. L. (2006). Sociocultural theory and the genesis of second language development. Oxford: Oxford University Press.

Larson-Freeman, D. (2005a). A Critical Analysis of Postmethod. ILI Language Teaching Journal, 1(1), 21-25.

Larson-Freeman, D. (2005b). On the Appropriateness of Language Teaching Methods in Language and Development. ILI Language Teaching Journal, 1 (2), 1-14.

Liu, D. (1995). Comments on B. Kumaravadivelu's "The post-method condition: (E) merging strategies for second/foreign language teaching": "Alternative to" or "addition to "method? TESOL Quarterly, 29, 174-177.

Mulaik, S. A. \& Millsap, R. E. (2000). Doing the Four-step Right. Structural Equation Modeling, 7, 36-73.

Muthén, L. K., \& Muthén, B. O. (2010). MPlus user's guide (6th ed.). Los Angeles, CA: Author.

Nikitina, L., Zuraidah M.D., \& Loh, S.C. (2016). Construction and Validation of a Questionnaire on Language Learning Motivation. Zbornik Instituta za Pedagoska Istrazivanja, 48(2), 284-300.

Pallant, J. (2011). SPSS Survival Manual. 4th ed. Maidenhead: Open University Press.

Prabhu, N. S. (1990). There is No Best Method-Why? TESOL Quarterly, 24(2), 161176.

Prabhu, N. S. (1992). Second language pedagogy. Oxford: Oxford University Press.

Razmjoo, S. A., Ranjbar, H., \&Hoomanfard, M. H. (2013). On the Familiarity of Iranian EFL Teachers and Learners with Post-method, and Its Realization. International Journal of Language Learning and Applied Linguistics World (IJLLALW), 4 (1), 1-12.

Richards, J. C., \& Farrell, T. (2005). Professional development for language teachers. New York: Cambridge University Press.

Richards, J. C., \& Rodgers, T. S. (2001). Approaches and methods in language teaching. Cambridge: Cambridge University Press.

Tudor, I. (2003). Learning to Live with Complexity: Towards an Ecological Perspective on Language Teaching. System, 31, 1-12.

Widdowson, H. G. (1990). Aspects of Language Teaching. Oxford: Oxford University Press.

Worthington, R., \& Whittaker, T. (2006). Scale Development Research: A Content Analysis and Recommendations for Best Practices. The Counseling Psychologist, 34, 806-838.

Zwick, W. R., \& Velicer, W. F. (1986). Comparison of Five Rules for Determining the Number of Components to Retain. Psychological Bulletin, 99(4), 432-442. 